\title{
A PÁRIZSI PASTEUR INTÉZET VILÁGHÍRŰ MAGYAR MOLEKULÁRIS BIOLÓGUSA: ULLMANN ÁGNES ${ }^{1}$
}

\section{THE WORLD-FAMOUS HUNGARIAN MOLECULAR BIOLOGIST OF THE INSTITUTE PASTEUR PARIS: AGNES ULLMANN}

\author{
Venetianer Pál \\ az MTA rendes tagja, Szegedi Biológiai Kutatóközpont Biokémiai Intézet
}

\section{ÖSSZEFOGLALÁS}

A cikk ismerteti a 2019 februárjában, 92 éves korában Párizsban elhunyt Ullmann Ágnes életútját, az erdélyi születéstől és kolozsvári egyetemtől, a Pázmány Péter Tudományegyetemen szerzett vegyészi diplomán és a Straub-intézetben kezdett kutatói pályakezdésen át, a kalandos, 1960-as nyugatra szökésig, majd a Pasteur Intézetben a Nobel-díjas François Jacob és Jacques Monod mellett kibontakozó világkarrierig. E kutatói pálya legfontosabb eredményei: a lac-operon promoter-régiójának strukturális és funkcionális elemzése, a $\beta$-galaktozidáz $\alpha$ - és $\omega$-komplementációjának felfedezése, a katabolit-represszió mechanizmusának és benne a ciklikus-AMP szerepének tisztázása, a Bordatella pertussis patomechanizmusának felderítése.

\section{ABSTRACT}

This paper describes the life history of Agnes Ullmann who died in February 2019 in Paris, shortly before her $92^{\text {nd }}$ birthday. She was born in Transylvania, started her university studies in Kolozsvár, obtained her degree in chemistry in Budapest, started her scientific career in the Institute led by F. B. Straub, escaped adventurously through the iron curtain in 1960, and became a world-famous scientist in the Institute Pasteur Paris on the side of the Nobelists François Jacob, and Jacques Monod. Her most important scientific achievements: the structural and functional analysis of the promoter-region of the lac-operon, the discovery of the $a$ - and $\omega$-complementation of the $\beta$-galactosidase, the clarification of the mechanism of the catabolite repression, and the role of cyclic-AMP in it, new discoveries in the pathomechanism of Bordatelle pertussis.

Kulcsszavak: Erdős Tamás, Straub F. Brunó, François Jacob, Jacques Monod, Bordatella pertussis

Keywords: Tamás Erdős, Brunó F. Straub, François Jacob, Jacques Monod, Bordatella pertussis

${ }^{1}$ Rendhagyó biológussorsok a 20. században. Az MTA Tudomány- és Technikatörténeti Bizottság előadóülésén, Budapesten 2019. szeptember 13-án elhangzott előadás szerkesztett változata. 
Ebben a cikkben, először, meg szeretném indokolni, hogy miért nem tudok „sine ira et studio" írni tárgyamról, azaz elmondom, milyen volt személyes kapcsolatom Ullmann Ágnessel. Másodszor és legföképpen, a szimpózium címének megfelelően, Ágnes életét, sorsát ismertetném, és végül - csak röviden - összefoglalom, hogy mit köszönhet neki a tudomány.

Én 1957-ben kaptam meg tanári diplomámat az Eötvös Loránd Tudományegyetem (ELTE) biológia-kémia szakán. Eleve kutató szerettem volna lenni, de akkoriban éppen megszünt a biológus kutató szakos képzés, és az egyetem nem is hirdetett kutatói állásokat a végzők számára. Családunk barátjához, Szalai Sándor szociológus akadémikushoz fordultam, hogy nem

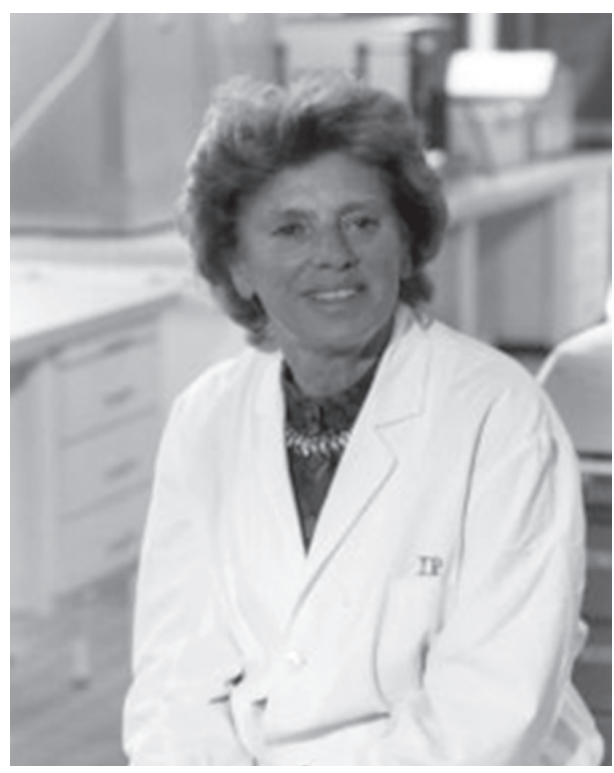

Ullmann Ágnes képe a 2019. novemberi emlékkonferencia meghívóján tud-e segíteni. Ö még az akadémiai apparátusban szereplőként ismerte Erdős Tamást, aki akkor a Korányi TBC-intézet biokémiai laboratóriumát vezette, és azt ajánlotta, hogy forduljak hozzá. Megkerestem tehát Erdőst, aki alaposan kifaggatott, majd ennek eredményeként adott egy ajánlólevelet feleségéhez, Ullmann Ágneshez, aki a Straub F. Brunó által vezetett Orvosi Vegytani Intézetben dolgozott a Budapesti Orvostudományi Egyetemen (BOTE, később Semmelweis Orvostudományi Egyetem - SOTE, ma Semmelweis Egyetem - SE). Így kerültem a Straub-intézetbe, Ullmann Ágnes mellé, az ő irányításával kezdtem kutatói pályámat. Együtt dolgoztunk 1960 nyaráig, amikor egy nap Ágnes bejelentette, hogy a hét végén Tamással vitorlázni mennek a Balatonra. Ha szép az idő, esetleg tovább maradnak. Ez a tovább örökösnek bizonyult, nyomtalanul eltűntek az intézetből, otthonukból és az országból. Öt évvel később az USA-ban találkoztam ismét Ágnessel, és azóta, haláláig baráti viszony volt közöttünk, ő ajánlott engem később Magyarországról elsőként EMBO- (European Molecular Biology Organization) tagságra, és én kezdeményeztem az ő jelölését MTA külső tagnak.

Elnézést ezért a szubjektív bevezetésért. Ezután már csak Ullmann Ágnesről fogok írni. Ágnes Erdélyben, Szatmárnémetiben született, 1927. április 14-én. Aradon, román gimnáziumban végezte a középiskolát, így magyar anyanyelve mellett románul, a magyar értelmiség második nyelvén, németül, és a román értelmiség második nyelvén, franciául is csaknem anyanyelvi szinten beszélt. Önéletrajzi vázlata szerint (Ullmann, 2012) gimnazistaként elsősorban a sport 
érdekelte, atlétikában, teniszben és pingpongban is kitűnt, számos érmet nyert. Késői önvallomása szerint a sportban tanulta meg azt a küzdőképességet és kitartást, ami sokat segített tudományos pályáján is. Érettségi után, 1945-ben a kolozsvári egyetem kémia szakára iratkozott be, de 1947-ban áttelepült Magyarországra, és itt a Pázmány Péter Tudományegyetemen kapta meg vegyészi diplomáját 1949-ben. Kutatói pályáját - ebben az évben - a Straub F. Brunó által vezetett Orvosi Vegytani Intézetben kezdte a Budapesti Orvostudományi Egyetemen. Első férje évfolyamtársa, Bihari István volt, őróla érdemes tudni, hogy később a Reanal gyár, majd a Chinoin vezetője is volt, és 1984-88 között az Országos Mủszaki Fejlesztési Bizottság (OMFB) elnöke. Ez a házasság azonban rövid életủ volt, második férje Erdős Tamás biokémikus lett, Szent-Györgyi Albert egykori munkatársa. Erdős, még a Szent-Györgyi-intézet kutatójaként, 1946-48-ban többször járt svédországi tanulmányúton, a Nobel-díjas Theodor Svedbergnél és Arne Tiseliusnál. 1949-ben annak a Magyar Tudományos Tanácsnak a titkára, azaz de facto vezetője lett, amelyet a „Párt” (Magyar Dolgozók Pártja) - Gerő Ernő terve szerint - az MTA tényleges leváltására hozott létre. Miután azonban - szovjet nyomásra - ez a terv megbukott, a tanácsot feloszlatták, Erdőst kirúgták állásából, és a pártból is kizárták. Ezután a budapesti és a debreceni egyetemen volt szerződéses biokémikus oktató. 1954ben rehabilitálták, és ekkor lett a Korányi TBC-Intézet biokémiai laboratóriumának vezetője. A következő periódusban igen aktív szerepet játszott a párt reformszárnyának aktivitásában, a Petőfi-körben. Az 56-os forradalomban az értelmiségi forradalmi tanács tagja lett. Ebben az időszakban Ágnes is elég aktív volt politikailag, egyik legjobb barátja volt Ádám György közgazdász, akit 1949-ben a Rajk-perben tíz évre ítéltek, majd 1954-ben rehabilitáltak, és forradalmi tevékenysége miatt - ugyanis ő volt az értelmiségi forradalmi tanács elnöke - 1957-ben ismét elítélték, ezúttal életfogytiglanra. 1957 márciusában Erdőst a forradalomban játszott szerepe miatt letartóztatták, de egy hónapi fogság után ítélet nélkül szabadlábra került. Ma már tudható, hogy szabadulását annak köszönhette, hogy aláírt egy beszervezési nyilatkozatot. Mikor én ezt a közelmúltban a jelentéseket tanulmányozó Németh Györgytől megtudtam, eléggé megrendített az információ. Az viszont megnyugtatott, hogy jelentései gyakorlatilag senkinek sem ártottak, zömmel tudománypolitikai tanácsokat próbált bennük adni az ország akkori vezetésének. Az ő számára viszont egyre nyomasztóbbá vált, hogy kiváló svéd kapcsolatait az állambiztonság megpróbálta felhasználni. Noha ez a jelentésekből nem derül ki, valószínünek látszik, hogy Ágnest is azért engedték ki Franciaországba 1958-ban, hogy rajta keresztül információkat nyerjenek a Pasteur Intézetről.

Egy kutató emigrációja - különösen, ha az nyilvánvalóan irreverzibilis - rendszerint a vonzás és a taszítás eredője. Ágnesnél a taszítást nyilván az a nyomasztó teher jelentette, amit férje helyzete jelentett. A vonzásról Ágnes beszámol ön- 
életírásában (Ullmann, 2012). Elmondja, hogy milyen hatással volt rá, amikor elolvasta az Ádám Györgytöl titokban megkapott Combat-ban (Albert Camus folyóirata) Jacques Monod 1948-as nyilatkozatát a liszenkoizmus elitéléséről, és emiatti szakítását a kommunista mozgalommal. Ágnes ekkor határozta el, hogy meg akarja ismerni a hősének, példaképének tekintett Monod-t. Amikor tehát 1958 januárjában kijutott Párizsba, a Pasteur Intézetbe, és ott François Gros mellett kezdett dolgozni, hamarosan bevallotta neki, hogy ö mindenáron szeretne kint maradni, de ezt egyszerủen nem teheti meg, mert akkor férjét nyilván soha nem engednék ki, sőt talán újra becsuknák. Gros azt mondta, hogy talán Monod, a részleg fönöke tudna segíteni, beszélt vele, és ennek eredményeként Monod meghívta Ágnest vacsorára, ahol ő részletesen beszámolt a helyzetükröl. Ekkor Monod ígéretet tett, hogy mindent elkövet a segítségükre, és megpróbálja kijuttatni mindkettőjüket. Ezután következett egy kétéves, hol reményt felcsillantó, hol kétségbeesésbe taszító periódus, amelyben Monod a legkülönbözőbb segítő, majd kudarcot valló közreműködőkkel próbálta megszervezni a házaspár megszöktetését. Ennek részletes elbeszélésére itt nincs hely. A szöktetés részletes története olvasható Sean Carroll Brave Genius című, Monod-ról és Albert Camus-röl szóló könyvében (Carroll, 2013). E könyv a két Nobel-díjas barátságáról szól, de harmadik hőse Ullmann Ágnes. A történetből két epizódot azért megemlítenék. Együttes munkánk két évében a pankreászamiláz sejtmentes rendszerben történő szintézisével foglalkoztunk. Az amiláz keményítőbontó enzim, és mérésére a keményítő mennyiségének csökkenését használtuk. Noha a keményítő színtelen, jóddal intenzív sötétkék szint ad, e szín halványulásával mértük az amiláz aktivitását. Nos, Ágnes ezt a reakciót használta a Monod-val folytatott titkos levelezésre. Egymásnak küldött Bartók- és Rosztropovics-lemezek borítójára írták színtelen keményítőoldattal a titkos üzeneteket, amelyeket a címzett jódoldattal tett láthatóvá. A másik, ponyvaregénybe illö epizód: az a terv is komolyan felmerült, hogy egy vándorcirkusz vinné ki az oroszlán ketrecében elrejtőzött házaspárt, míg az oroszlánt gyógyszerrel elaltatták volna.

1960 májusában Monod-t meghívta a Magyar Tudományos Akadémia. Vendéglátóit Monod megkérte, hogy vigyék el egy kirándulásra a Duna-kanyarba, a tolmácsként és kalauzként közreműködő Erdős-Ullmann-házaspár kíséretében. Ennek egyedüli célja az volt, hogy kinézzenek valahol az úton egy megfelelő helyet az embercsempész számára, a házaspár felvételére. Végül 1960 nyarán sikerült lefizetni egy brit lakókocsi osztrák soförjét, aki egy felfordított fürdőkád alatt elrejtve őket, sikeresen átvitte az autót a vasfüggönyön. Ez a siker szinte csoda volt, mert a határon közel egy órán át vizsgálták a rakományt, de nem fedezték fel a kád alatt rejtőző házaspárt. Monod rövidesen a Pasteur Intézetben szerzett állást Ágnesnek és a Gif-sur-Yvette-i CNRS Enzimológiai Intézetben Tamásnak. Innentől kezdve Ullmann Ágnes pályája töretlenül emelkedett. Ennek a pályának külső elismerései, sikerei a következők: 
1966-ban kapta meg a francia állampolgárságot. 1978-tól volt saját osztálya a Pasteur Intézetben (Service de Biochimie des Interactions Cellulaires). 1982-ben kapta meg a tudományos igazgatói címet, amelyet 1997-es nyugdíjazásáig töltött be. 1983-ban lett az EMBO tagja, 1995-ben kapta meg a Louis Pasteur-aranyérmet, 1996-ban a legnagyobb francia kitüntetést, a Becsületrendet. 1998-ban lett az MTA külső tagja. 2002-ben megkapta az európai mikrobiológia legnagyobb kitüntetését a Robert Koch-érmet, 2007-ben lett a római La Sapienza Egyetem díszdoktora, és 2011-ben kérte fel az Annual Review of Microbiology szerkesztősége a következő kötetet bevezetö, önéletrajzi visszaemlékezése megírására (Ullmann, 2012) - ilyen visszaemlékezéseket az Annual Review-k csak a tudományterület legnagyobb egyéniségeitől szoktak kérni. Nyugdíjazása után is, amíg egészségi állapota megengedte, mindennap bejárt az intézetbe, ekkoriban már rendszeresen járt haza is, nyaralni a tihanyi MTA Limnológiai Intézet vendégházába barátnőjével, Kulka Eszterrel, a nagy színész, Kulka János - aki Ágnes keresztfia volt édesanyjával. Az utolsó években azonban látása már annyira megromlott, hogy nem tudott autót vezetni, és olvasni sem. 2019. február 25-én hunyt el egyedül, párizsi otthonában.

Mielőtt szakmai eredményeit ismertetném, még néhány szó személyiségéről. A francia kolléga Philip Sansonetti megemlékezésében (Sansonetti, 2019) a legnyomatékosabb jelző Ágnes eleganciája. Eleganciájának, kiváló ízlésének és általános kultúrájának, műveltségének köszönhette, hogy a szakma szinte minden jelentős kortárs egyéniségének személyes jó barátja volt. Én, amikor megismertem, elsősorban páratlan manuális kísérleti ügyességét és gyorsaságát csodáltam. Önéletrajzi vázlatában megírta, hogy a Pasteurben töltött első napjaiban a folyosón egy kis csoportosulásba ütközött, a kollégák az újonnan vásárolt Spinco ultracentrifuga körül álldogáltak, ami nem akart elindulni. Ő odalépett, rögtön tudta, hogy mi a baj, és egy perc alatt megjavította. Ez az epizód sokat segített ottani elfogadásában. Imponáló volt, hogy vegyészi alapképzettsége és az ötvenes években nálunk uralkodó liszenkói áltudomány ellenére milyen remekül sajátította el a modern genetika és molekuláris biológia szemléletét és ismeretanyagát, és az, hogy noha soha nem tanult tanártól angolul, a szakirodalomból egyedül felszedett angol nyelvtudását milyen gyorsasággal és hatékonysággal fejlesztette folyékony társalgási és előadói szintre.

És befejezésként egy nagyon vázlatos áttekintés arról, hogy mit köszönhet neki a tudomány. A Straub-intézetben részt vett az akkoriban ott folyó, elöször az aktinnal, majd a vörös vértestek permeabilitásával kapcsolatos kutatásokban, de első önálló témája - amelybe én is bekapcsolódtam - egy specifikus fehérje, a pankreászamiláz bioszintézise volt sejtmentes rendszerben. Ez a munka nagyon ígéretesen indult, de sajnos kudarccal végződött, egyikünk számára sem hozott dicsőséget. Magyarországról az első - és utolsó - jelentős eredménye a férjével, Erdős Tamással végzett munka a sztreptomicin hatás- 
mechanizmusáról, amely két Nature-cikket eredményezett (Erdős-Ullmann, 1959, 1960).

Párizsban kezdett új élete jellemzésére a legtalálóbban egyik Nobel-díjas társszerzője, Jacob mondása illik: „A siker titka: jó időben kell lenni, jó helyen.” Ebben az időszakban ugyanis itt született meg szakmánk két korszakalkotó eredménye, a génműködés szabályozásának általános elmélete (Jacob-Monod, 1961), és a messenger-RNS létének kísérleti bizonyítása (Gros et al., 1961). Ez a mühely akkor valóban a molekuláris biológiai kutatás csúcsintézménye volt, és Ágnes a két későbbi Nobel-díjas, Jacob és Monod legfontosabb partnere lett, együttmüködésük eredménye nyolc közös cikk. Ezek többsége természetesen a lac-operon működéséről szólt, figyelemre méltó azonban, hogy Monod-t ebben az időben már elsősorban másik fontos felfedezése, az allosztéria elmélete foglalkoztatta. Ennek az elméletnek az első kísérleti igazolását is Ullmann szolgáltatta (Ullmann et al., 1964). A lac-operonnal kapcsolatos első fontos cikkük az operon promoterrégiójának pontos behatárolása és önálló funkciójának igazolása, azáltal, hogy egy másik génnel fuzionálva, annak kifejeződését képes irányítani. Ez a munka tekinthető az ,in vivo genetic engineering” első sikeres példájának (Jacob et al., 1965). A következő két fontos felfedezése - ugyanebben a rendszerben - a $\beta$-galaktozidáz úgynevezett $\omega$ - és $\alpha$-komplementációja. Az utóbbi tette lehetôvé a későbbi ,genetic engineering” kísérletekben használt plazmid-vektorokban világszerte legtöbbet alkalmazott egyszerü indikátorként a $\beta$-galaktozidáz színreakciót (Ullmann et al., 1965, 1967, 1968). Végül, e pályaszakasz betetőzéseként publikált egy egylépéses affinitáskromatográfiás tisztítási módszert ezeknek a $\beta$-galaktozidáz, $\alpha$-peptidet tartalmazó hibrid fehérjéknek a tisztítására (Ullmann, 1984). A lac-operon szabályozásával indult, de sokkal szélesebb területet ölelt fel a következő pályaszakasz, az úgynevezett „katabolit represszió” jelenségének és a ciklikus-AMP szabályozó szerepének vizsgálata. Ezt már önálló témavezetőként végezte, és ezen a területen munkatársaival, tanítványaival ötven közleményt publikáltak (Ullmann-Danchin, 1983). A ciklikus-AMP vezetett át pályája következő szakaszába. A kiinduló pont az az 1982-ben publikált tény volt, hogy a ciklikus-AMP szintéziséért felelős enzim, az adenilát-cikláz a szamárköhögés kórokozójának a Bordatella pertussisnak a toxinja, amely felelős a baktérium patogenicitásáért. A nyolcvanas évek végén a Human Frontiers program keretében egy széles körü nemzetközi együttmüködésben jelentős összegű grantet nyert el e baktérium patogenitási hatásmechanizmusának vizsgálatára. E munkák eredményeiről számolt be magyar akadémiai székfoglalójában és egy összefoglaló cikkben (Ladant-Ullmann, 1999). Jelentős lépéseket tettek egy vakcina kidolgozása felé is (Fayolle et al., 1999).

És végül, sokat tett korán elhunyt mestere és példaképe, Jacques Monod emlékének ápolásáért. Először, a szintén Nobel-díjas André Lwoff-fal együtt szer- 
kesztették az 1978-ban megjelent Monod-emlékkötetet, majd a negyedszázaddal később, 2004-ben megjelent második kiadást már Ágnes egyedül szerkesztette (Ullmann, 2004), és ő tartotta a nyitó plenáris előadást azon a 2010-ben Ravellóban rendezett szimpóziumon, amelyet Monod születésének százéves és híres könyve, a Véletlen és szükségszerüség megjelenésének negyvenéves évfordulóján tartottak.

Zárómondat: emlékére a párizsi Pasteur Intézet parkjának rózsaligetét róla nevezték el, és 2019 novemberében Párizsban egynapos emlékkonferenciát rendeztek tiszteletére, Agnes Ullmann, grande figure de la biologie moleculaire címmel, amelyen közel kétszázan vettek részt, hogy hódoljanak a szakma és a Pasteur Intézet grande dame-jának.

\section{IRODALOM}

Carroll, S. B. (2013): Brave Genius. New York: Crown Publishers

Erdos, T. - Ullmann, A. (1959): Effect of Streptomycin on the Incorporation of Amino-acids Labelled with Carbon-14 into Ribonucleic Acid and Protein in a Cell-free System of a Mycobacterium. Nature, 183, 618-619. DOI: 10.1038/183618a0

Erdos, T. - Ullmann, A. (1960): Effect of Streptomycin on the Incorporation of Tyrosine Labelled with Carbon-14 into Protein of Mycobacterium Cell Fractions in vivo. Nature, 185, 100-101. DOI: $10.1038 / 185100 \mathrm{a} 0$

Fayolle, C. - Ladant, D. - Karimova, G. et al. (1999): Therapy of Murine Tumors with Recombinant Bordetella Pertussis Adenylate Cyclase Carrying a Cytotoxic T Cell Epitope. Journal of Immunology, 162, 4157-4162. https://www.jimmunol.org/content/162/7/4157.long

Gros, F. - Hiatt, H. - Gilbert, W. et al. (1961): Unstable Ribonucleic Acid Revealed by Pulse-labeling of Escherichia Coli. Nature, 190, 581-585. DOI: 10.1038/190581a0

Jacob, F. - Monod, J. (1961): Genetic Regulatory Mechanisms in the Synthesis of Proteins. Journal of Molecular Biology, 3, 318-356. DOI: 10.1016/s0022-2836(61)80072-7, http://web.mit. edu/7.70/restricted/pdfs/jacob_monod.pdf

Jacob, F. - Ullmann, A. - Monod, J. (1965): Deletions fusionnant l'operon lactose et un operon purine chez Escherichia coli. Journal of Molecular Biology, 31, 704-719. DOI: 10.1016/S00222836(65)80137-1

Ladant, D. - Ullmann, A. (1999): Bordetella Pertussis Adenylate Cyclase: A Toxin with Multiple Talents. Trends in Microbiology, 7, 172-176. DOI: 10.1016/s0966-842x(99)01468-7

Sansonetti, P. (2019): In memoriam Agnes Ullmann. https://fems-microbiology.org/agnes-ullmann1927-2019-c/

Ullmann, A. (1984): One-step Purification of Hybrid Proteins Which Have $\beta$-Galactosidase Activity. Gene, 29, 27-31. DOI: 10.1016/0378-1119(84)90162-8

Ullmann, A. (ed.) (2004): Origins of Molecular Biology. A Tribute to Jacques Monod. Washington: ASM Press

Ullmann, A. (2012): A Fortunate Journey on Uneven Grounds. Annual Review of Microbiology, 66, 1-24. https://www.annualreviews.org/doi/pdf/10.1146/annurev-micro-092611-150133

Ullmann, A. - Danchin, A. (1983): Role of Cyclic AMP in Bacteria. In: Greengard, P. - Robison, G. A. (eds.): Advances in Cyclic Nucleotide Research. New York: Raven Press, 15, 1-53. https:// www.researchgate.net/publication/285438006_Role_of_cyclic_AMP_in_bacteria 
Ullmann, A. - Jacob, F. - Monod, J. (1967): Characterization by in Vitro Complementation of a Peptide Corresponding to an Operator Proximal Segment of the $\beta$-galactosidase Structural Gene of Escherichia coli. Journal of Molecular Biology, 24, 339-350. DOI: 10.1016/00222836(67)90341-5

Ullmann, A. - Jacob, F. - Monod, J. (1968): On the Subunit Structure of Wild-type Versus Complemented $\beta$-galactosidase of Escherichia coli. Journal of Molecular Biology, 32, 1-13. DOI: 10.1016/0022-2836(68)90140-x

Ullmann, A. - Perrin, D. - Jacob, F. et al. (1965): Identification par complementation in vitro et purification d'un segment peptidique de la $\beta$-galactosidase d'Escherichia coli. Journal of Molecular Biology, 12, 918-923.

Ullmann, A. - Vagelos, P. R. - Monod, J. (1964): The Effect of 5'adenylic Acid upon the Association between Bromthymol Blue and Muscle Phosphorylase b. Biochemical and Biophysical Research Communications, 17, 86-89. 